\title{
Phytochemical analysis, antibacterial and antioxidant activity determination of Ocimum sanctum
}

\begin{abstract}
The objective was to analyse phytochemical constituents from the leaves of Ocimum sanctum using suitable solvents and extraction technique and to evaluate the in-vitro antibacterial and in-vitro antioxidant activities of leaf extract of Ocimum sanctum. In present work, Soxhlet extraction and maceration extractions were applied to the fresh leaves of the Ocimum sanctum by using absolute ethanol. Phytochemical analysis for the important chemical constituents from ethanolic extract was carried out. Antimicrobial activity of Ocimum sanctum extract was carried out using Well Diffusion method by comparing the clear inhibition zone of standard antibiotic and the extracts on the Mueller Hinton agar. Antioxidant activity of Ocimum sanctum was carried out performing total phenolic content test and DPPH to identify the percentage of scavenging by the chemical constituents. For phytochemical analysis, only test for alkaloids, test for terpenoids and test for carbohydrates showed positive results for Ocimum sanctum extract. For antibacterial screening, all the concentrations of OSESE showed negative results due to low concentration of extract being used. For antioxidant analysis, total phenolic contents and DPPH radical scavenging showed antioxidant result for OSESE. It is concluded that Ocimum sanctum is a very essential plant medicinally. A long term research project is a must to evaluate the pharmacological uses of extracts with different solvents that can be used to isolate the pure and high yield of chemical constituents from the plants.
\end{abstract}

Keywords: soxhelt, maceration, ethanol, phytochemical, antibacterial, anti-oxidant
Volume 6 Issue 6 - 2018

\author{
Kang Zhi Xia, Nabila Perveen, Naeem Hasan \\ Khan \\ Department of Pharmaceutical Chemistry,AIMST University, \\ Malaysia
}

\begin{abstract}
Correspondence: Naeem Hasan Khan, Department of Pharmaceutical Chemistry, Faculty of Pharmacy, AIMST University, Bedong 08100, Kedah Darul Aman, Malaysia, Tel 0060
\end{abstract} I69372470, Email naeemhsherazi@hotmail.com

Received: November 18, 2018 | Published: December 18, 2018

\section{Introduction}

The plant's height is up to $1 \mathrm{~m}$, with branches, carrying with a pungent aromatic odour smell, the branchlets and new growth pubescent with soft white hairs. The Ocimum sanctum's leaves with blades elliptic to elliptic-oblong approximately 3 to $6 \mathrm{~cm}$ long, width is $1-2.5 \mathrm{~cm}$, cuneate to attenuate at base, obtuse to acute at apex, entire to remotely serrate at margins, pubescent on both surfaces but especially on the nerves beneath. For the flowers terminal, the slender racemes or panicles are 4 to $12 \mathrm{~cm}$ long with the width of 1 to $1.5 \mathrm{~cm}$, the bracteoles are 2 to $3 \mathrm{~mm}$ long, ovate, acuminate, ciliate; flowers in verticils, on the pedicels are 2 to $4.5 \mathrm{~mm}$ long; at anthesis, the calyx c is $2.5 \mathrm{~mm}$ long, in fruit up to $5 \mathrm{~mm}$ long, glabrous within, the upper lip suborbicular, reflexed, short-apiculate, the lower lip longer than the upper lip, the teeth 4, lanceolate; corolla pale pink, pale lavender or white, to $4 \mathrm{~mm}$ long; filaments of stamens exerted, slender, the upper pair of each with a small, bearded basal appendage. The appearance of fruit is purple-green to brown, broadly ellipsoid, approximately $0.8-1.2 \mathrm{~mm}$ long, smooth to minutely pitted, swelling in water. ${ }^{1,2}$ The leaves and flowers of Ocimum sanctum are shown in Figure 1.

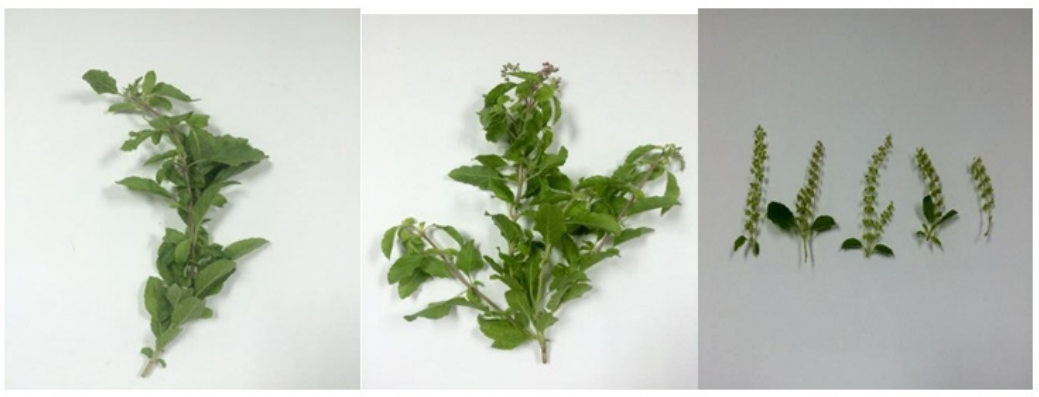

Figure I The leaves and flowers of Ocimum sanctum.

Other names of Ocimum sanctum are Tulsi, Tulasi, Gouri, Bhuteshta, Bhutaghini, Nagamata, Surasah, Mal-Tulasi, Krsiatulasi, Indian Basil, Holy Basil, Sacred Basil, Nalla Thulasi, Raihan, LoLe, Basil Icum, Basilic, Basilienkraut, Selasih, Kemangi, Basilico, Meboki, Selaseh, Belanoi, Sulasi, Man Jericao, Bazilik, Albahaca, Suwenda-Tala, Maduru-Tala, Basilkort, Horopa, Manghk, Krapow, Bai Horapa, Rau Que. ${ }^{3,4}$ It is available in India, Sri Lanka, Himalaya, Bangladesh, South West Asia, Burma, China, Thailand, Malaysia. In addition, it is also available at dry sandy areas in Hainan, Sichuan, Taiwan Cambodia, Indonesia, Laos, Myanmar, Philippines, Vietnam; Africa, South West Asia, Australia. ${ }^{2}$ Ocimum sanctum, the Queen of medicinal herbs is the holiest and the most valuable of the many healing and ill-health giving herbs of the suitable way. ${ }^{5,6}$ The blessed Basil or Tulsi is significant in the traditional Ayurvedic and Unani system. ${ }^{5}$ In India, Ocimum sanctum are believed that it can be given the treatment of bronchitis, bronchial asthma, malaria, diarrhoea, dysentery, skin diseases, arthritis, painful eye diseases, increase in body temperature and also insect bite. More importantly it has anticancer, antifungal, antihypergycaemic, antibacterial, in treatment of nausea and vomiting, protection against liver and heart, analgesic, adaptogenic and diaphoretic actions. It improves the body immune system, reproductive system, CNS, CVS, gastrointestinal tract system, urinary system and also blood circulation. ${ }^{4}$ Table 1 show the nutritional facts about Ocimum sanctum. 
Table I Nutritional highlight of Ocimum sanctum

\begin{tabular}{lc}
\hline In fresh Tulsi, five leaves were tested. $(2.5 \mathrm{~g})$ \\
\hline Calories & 0.675 \\
Protein & $0.064 \mathrm{~g}$ \\
Carbohydrate & $0.108 \mathrm{~g}$ \\
Total Fat & $0.015 \mathrm{~g}$ \\
Fiber & $0.098 \mathrm{~g}$ \\
\hline
\end{tabular}

\section{Methods}

\section{Collection and preparation of plant materials}

Green and fresh 557g of Ocimum sanctum was collected from the plants. The leaves were cleaned by distilled water and then leaves were separated from the branches manually. The separated leaves were weighed again and net weight was $349.64 \mathrm{~g}$ and allowed for air drying under the room temperature to avoid destruction of active group in the leaves. The dried leaves were crushed by using hand into very small pieces.

\section{Maceration}

The $25.0 \mathrm{~g}$ of crushed raw material was subjected to maceration with $200 \mathrm{ml}$ of absolute ethanol in round bottom flask and sealed with the aluminium foil and kept in the dark for seven days. The round bottom flask was shaken throughout to ensure uniform and complete extraction. The mixture was filtered by using clean Muslin cloth and the filtrate was collected in a cleaned beaker. The residue of maceration extract and filtrate of maceration were separated and being kept inside the cabinet for further screening.

\section{Soxhlet extraction}

$26.0 \mathrm{~g}$ of the crushed powder form was placed inside a thimble already fixed with the chromatographic paper. Ethanol added was $350 \mathrm{ml}$ for the extraction and poured into the round bottom flask of Soxhlet apparatus. The temperature was kept at $70^{\circ} \mathrm{C}$ and maintained throughout the process. The whole process took about 30 hours to complete till the clearance of colour extract. The residue of maceration extract and filtrate of maceration were separated and being kept inside the cabinet for further screening.

\section{Evaporation}

The evaporation was carried out from the extract (Soxhlet and Maceration) in a rotary evaporator. The temperature was set at $70^{\circ} \mathrm{C}$ throughout the evaporation and concentration. The extracts of Soxhlet and maceration, after evaporation, were $88 \mathrm{ml}$ and $25 \mathrm{ml}$ respectively.

\section{Phytochemical screening ${ }^{7-12}$}

The results of phytochemical analysis is recorded and tabulated in Table $2 .^{7-12}$

Table 2 Results for qualitative phytochemical screening

\begin{tabular}{lllll}
\hline No. & $\begin{array}{l}\text { Phytochemical } \\
\text { Tests }\end{array}$ & \multicolumn{2}{l}{$\begin{array}{l}\text { Ethanolic } \\
\text { maceration }\end{array}$} & $\begin{array}{l}\text { Ethanolic Soxhlet } \\
\text { Sample }\end{array}$ \\
\hline & & Filtrate & Residue & \\
\hline I & Alkaloids & + & + & + \\
2 & Reducing Sugar & - & - & - \\
3 & Saponins & - & - & - \\
4 & Terpenoids & + & + & + \\
5 & Antraquinones & - & - & - \\
6 & Glycosides & - & - & - \\
\hline
\end{tabular}

Table Continued....

\begin{tabular}{lllll}
\hline No. & $\begin{array}{l}\text { Phytochemical } \\
\text { Tests }\end{array}$ & \multicolumn{2}{l}{$\begin{array}{l}\text { Ethanolic } \\
\text { maceration }\end{array}$} & $\begin{array}{l}\text { Ethanolic Soxhlet } \\
\text { Sample }\end{array}$ \\
\hline 7 & Tannins & - & - & - \\
8 & Flavonoids & - & - & - \\
9 & Carbohydrate & + & + & + \\
\hline
\end{tabular}

+ presence, - absence

\section{Methodology for determination of antibacterial} activity Preparation of Luria Bertani broth media

$2.0 \mathrm{~g}$ of Luria Bertani broth was dissolved in $100 \mathrm{ml}$ distilled water. Then, $10 \mathrm{ml}$ of Luria Bertani broth was poured into each 4 universal bottles and subjected to the autoclave at high pressure saturated steam $121^{\circ} \mathrm{C}$ for around 1 hour in the laboratory. ${ }^{13-17}$

\section{Preparation of Muller Hinton Broth}

$38.0 \mathrm{~g}$ Muller Hinton Broth was dissolved into $1000 \mathrm{ml}$ of distilled water and poured into two $500 \mathrm{ml}$ of Scott bottles. After that, the two Scott bottles were taken to autoclave at high pressure saturated steam $121^{\circ} \mathrm{C}$ for around 1 hour in the Biotechnology laboratory. After the autoclaving have done, the sufficient sterilized quantity of Muller Hinton agar was poured into the sterilized petri plates and was allowed to solidify. Agar plates were stored in incubator at about $37^{\circ} \mathrm{C} .{ }^{13-17}$

\section{Bacteria strains cultures}

Bacteria strains of Bacillus subtilis, Pseudomonas aeruginosa, Escherichia coli and Streptococcus pyogenes were cultured using Luria Bertani broth in 4 different universal bottles. The bacterial strains stored in the universal bottles were left shaking incubator for 24 hours at $37^{\circ} \mathrm{C}$ at $180 \mathrm{rpm}$. The next days, the bacteria strains which has grown in Luria Bertani broth is then cultured into Muller Hinton agar. $^{16}$

\section{Dilution of extracts ${ }^{16}$}

(dissolved in sterilized distilled water)

a. To prepare $1.0 \mathrm{mg} / \mathrm{ml}$ of the extract, $10 \mathrm{mg}$ of the extract was dissolved using $10 \mathrm{ml}$ of sterilized distilled water.

b. To prepare $5.0 \mathrm{mg} / \mathrm{ml}$ of the extract, $50 \mathrm{mg}$ of the extract was dissolved using $10 \mathrm{ml}$ of sterilized distilled water.

c. To prepare $10.0 \mathrm{mg} / \mathrm{ml}$ of the extract, $100 \mathrm{mg}$ of the extract was dissolved using $10 \mathrm{ml}$ of sterilized distilled water.

\section{Well Diffusion test preparation in laminar air flow} cabinet $^{16,17}$

i. $1 \mathrm{mg} / \mathrm{ml}$ of ciprofloxacin was used as a positive control and sterilized distilled water was used as a negative control.

ii. Marker pen was used to label the bottom of the prepared petri dish.

iii. $100 \mu 1$ of bacterial strain (Bacillus subtilis) was spread onto the surface of agar by using spreader.

iv. Five different spot corresponding to the label around 6 to $8 \mathrm{~mm}$ were punched aseptically by using cork-borer.

v. Each holes was filled with ciprofloxacin, sterilized distilled water, $1 \mathrm{mg} / \mathrm{ml}$ of extract, $5 \mathrm{mg} / \mathrm{ml}$ of extract and $10 \mathrm{mg} / \mathrm{ml}$ of extract respectively by using $100 \mu 1$ micropipette.

vi. The procedure was repeated for another three bacterial strains (Pseudomonas aeruginosa, Escherichia coli and Streptococcus pyogenes).

vii. After that, the agar plates were covered and subjected to incubate at $37^{\circ} \mathrm{C}$ for 24 hours.

viii. Antimicrobial activity is determined by measuring with the inhibition zone. 


\section{Results of antibacterial activity}

Result for the Well Diffusion Test. Table 3 indicates the zone of inhibition in $\mathrm{mm}$. In present antibacterial study, two different extracts with three different concentrations were investigated to detect the zone of inhibition against Bacillus subtilis, Pseudomonas aeruginosa, Streptococcus pyogenes and Escherichia coli. Ciprofloxacin was used as a positive control and sterilized distilled water was used as a negative control. As a result, there is no antibacterial inhibition zone occurred in the most of the agar plates. This may be due to low concentration of the extract being used. Low concentration of the Ocimum sanctum was unable to produce any antibacterial effect against the bacteria strains in the agar plate. Figure 2, Figure 4, Figure 6 and Figure 8 shows the ethanolic maceration extract and Figure 3, Figure 5, Figure 7 \& Figure 9 indicates the ethanolic Soxhlet extract on the agar plate. All Figures shown at lower region, from 2-9, showed that the agar plates do not have any antibacterial activity by well diffusion method. There was an absence of zone of inhibition for each of the different concentration used by the extract solution..$^{16,17}$

Table 3 Zone of inhibition in $\mathrm{mm}$

\begin{tabular}{|c|c|c|c|c|c|c|}
\hline Microorganisms & Concentrated extract & I mg/ml & $5 \mathrm{mg} / \mathrm{ml}$ & $10 \mathrm{mg} / \mathrm{ml}$ & Ciprofloxacin & Sterilized distilled water \\
\hline \multirow{2}{*}{ Bacillus subtilis } & Ethanolic Maceration & - & - & - & 24 & - \\
\hline & Ethanolic Soxhlet & - & - & - & 24 & - \\
\hline \multirow{2}{*}{ Pseudomonas aeruginosa } & Ethanolic Maceration & - & - & - & 26 & - \\
\hline & Ethanolic Soxhlet & - & - & - & 24 & - \\
\hline \multirow{2}{*}{ Streptococcus pyogenes } & Ethanolic Maceration & - & - & - & 26 & - \\
\hline & Ethanolic Soxhlet & - & - & - & 26 & - \\
\hline \multirow{2}{*}{ Escherichia coli } & Ethanolic Maceration & - & - & - & 24 & - \\
\hline & Ethanolic Soxhlet & - & - & - & 24 & - \\
\hline
\end{tabular}

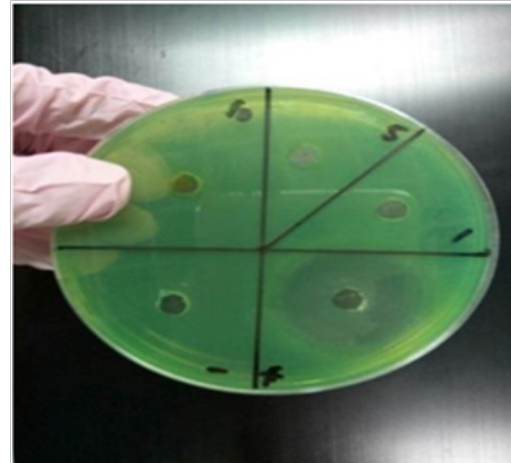

Figure 2 Ethanolic maceration extract on the agar plate.

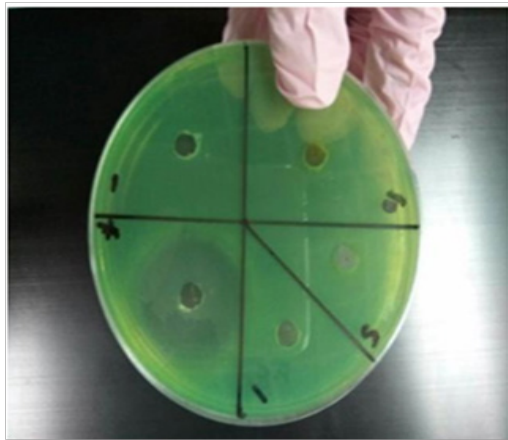

Figure 3 Ethanolic Soxhlet extract on the agar plate.

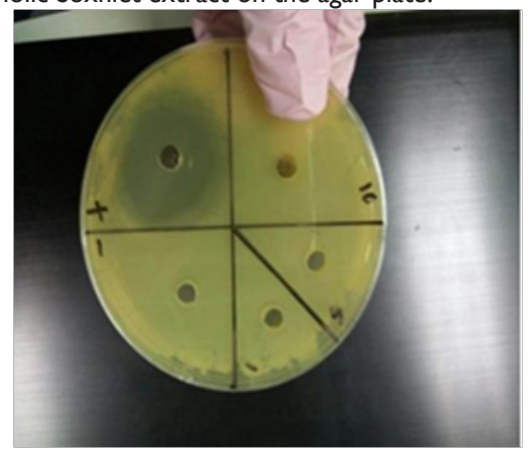

Figure 4 Ethanolic maceration on the agar plate.

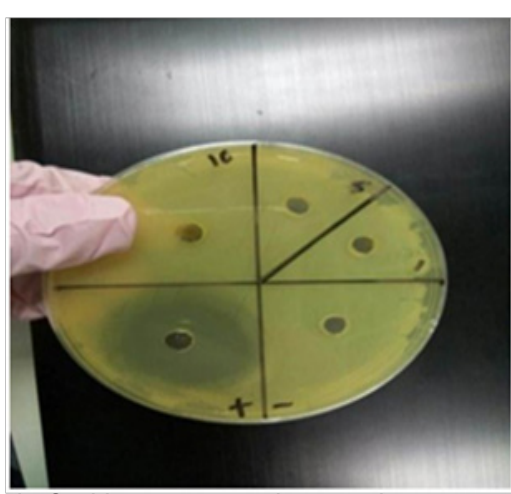

Figure 5 Ethanolic Soxhlet extract on the agar plate.

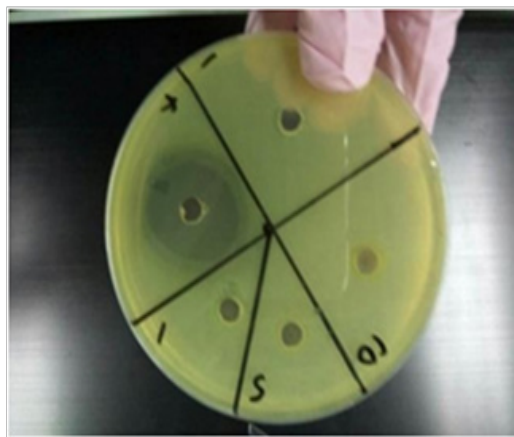

Figure 6 Ethanolic maceration extract on the agar plate.

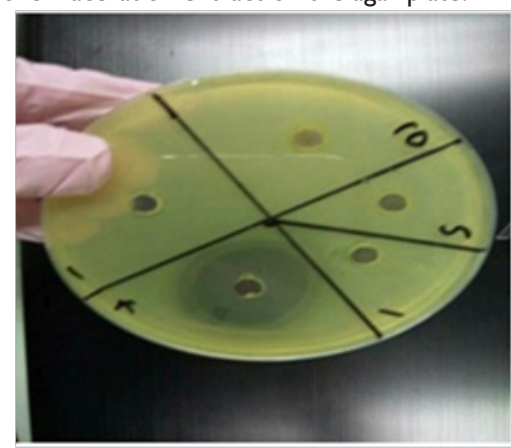

Figure 7 Ethanolic Soxhlet extract on the agar plate. 


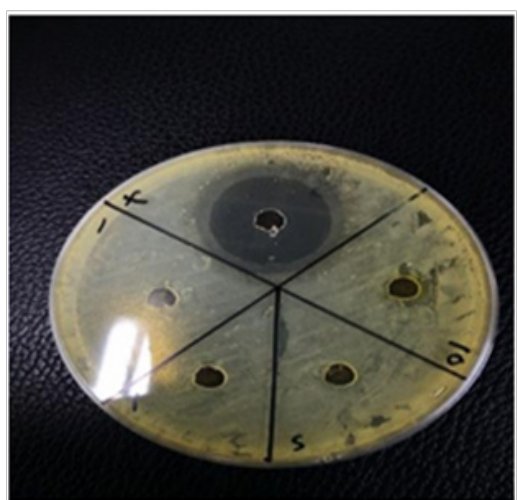

Figure 8 Ethanolic maceration extract on the agar plate.

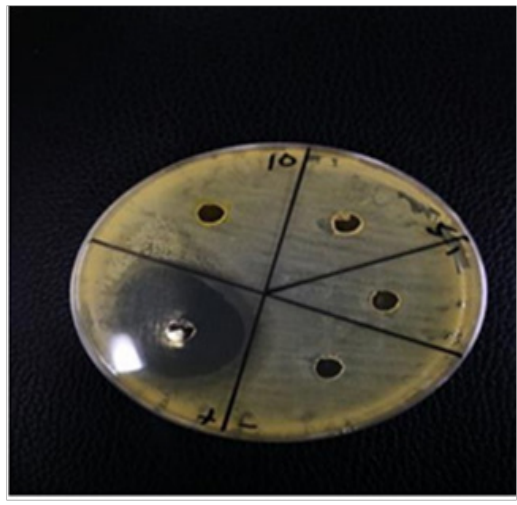

Figure 9 Ethanolic Soxhlet extract on the agar plate.

\section{Pseudomonas aeruginosa}

Figure 2 \& Figure 3

\section{Escherichia coli}

Figure $4 \&$ Figure 5

\section{Bacillus subtilis}

Figure 6 \& Figure 7

\section{Streptococcus pyogenes}

Figure 8 \& Figure 9

All Figures from 2-9 showed that the agar plates do not have any antibacterial activity determination by well diffusion method. There was an absence of zone of inhibition for each of the different concentration used by the extract solution.

\section{Antioxidant activity determination}

\section{Methodology for determination of antioxidant activity}

Total phenolic contents analysis (TPC) ${ }^{18}$ : For the total phenolic contents analysis, Folin-Ciocalteau (FC) assay was applied to Ocimum sanctum ethanolic Soxhlet extract to find out the total phenolic content of this extract. In this analysis, the standard used was Gallic acid and the measurement was done at $\lambda$ max $765 \mathrm{~nm}$. Gallic acid standard calibration curve was generated as shown in Graph 1 and the regression value was 0.9884 . From the absorbance obtained, the amount of the phenolic content measured as Gallic acid equivalent (GAE) using FC method. The total phenolic content obtained at the concentration of $1.0 \mathrm{mg} / \mathrm{ml}$ was found to be the highest when compared to other lower concentration extract solution. As a result, the higher the concentration of the stock solution used for this analysis, the higher the Gallic acid equivalent (GAE). ${ }^{19-25}$

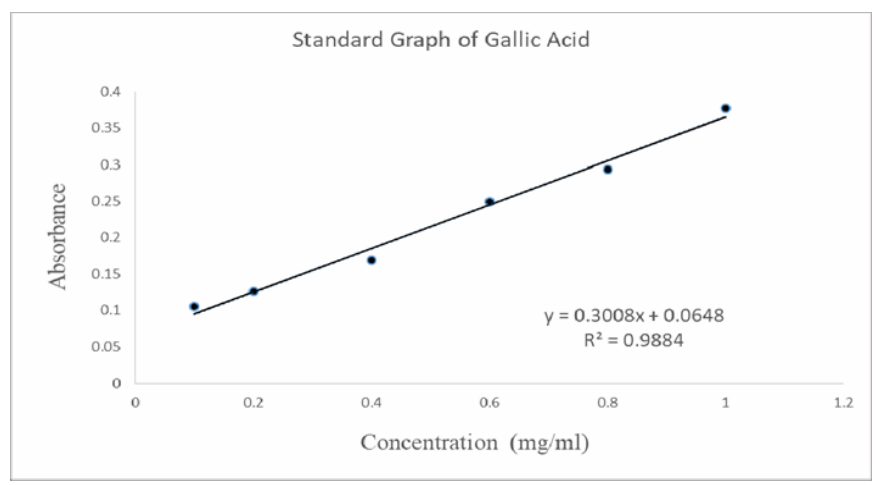

Graph I Standard graph of the Gallic acid plotted from the series of absorbance obtained from UV-Visible Spectrophotometer.

\section{Extract preparation}

i. To prepare $1 \mathrm{mg} / \mathrm{ml}$ of the extract solution, $10 \mathrm{mg}$ of the extract was dissolved using $10 \mathrm{ml}$ of ethanol.

ii. To prepare $0.8 \mathrm{mg} / \mathrm{ml}$ of the extract solution, $8 \mathrm{ml}$ of the $1 \mathrm{mg} / \mathrm{ml}$ of the extract solution was dissolved using $10 \mathrm{ml}$ of the ethanol.

iii. To prepare $0.6 \mathrm{mg} / \mathrm{ml}$ of the extract solution, $7.5 \mathrm{ml}$ of the $0.8 \mathrm{mg} /$ $\mathrm{ml}$ of the extract solution was dissolved using $10 \mathrm{ml}$ of the ethanol.

iv. To prepare $0.4 \mathrm{mg} / \mathrm{ml}$ of the extract solution, $6.67 \mathrm{ml}$ of the $0.6 \mathrm{mg} /$ $\mathrm{ml}$ of the extract solution was dissolved using $10 \mathrm{ml}$ of the ethanol.

v. To prepare $0.2 \mathrm{mg} / \mathrm{ml}$ of the extract solution, $5 \mathrm{ml}$ of the $0.4 \mathrm{mg} / \mathrm{ml}$ of the extract solution was dissolved using $10 \mathrm{ml}$ of the ethanol.

vi. To prepare $0.1 \mathrm{mg} / \mathrm{ml}$ of the extract solution, $5 \mathrm{ml}$ of the $0.2 \mathrm{mg} / \mathrm{ml}$ of the extract solution was dissolved using $10 \mathrm{ml}$ of the ethanol.

\section{Preparation of sample extract, blank and standard ${ }^{16,17}$}

i. $0.5 \mathrm{ml}$ of the extract solution $(1.0 \mathrm{mg} / \mathrm{ml})$ was added with the $2.5 \mathrm{ml}$ of the $0.75 \%$ sodium bicarbonate and $2.5 \mathrm{ml}$ of the $1 \%$ Folin-Ciocalteu's reagent.

ii. The sample mixtures were incubated at $45^{\circ} \mathrm{C}$ for 15 minutes. The UV absorbance was detected at $\lambda$ max $765 \mathrm{~nm}$.

iii. The steps were repeated by using other concentration of extract solution $(0.8 \mathrm{mg} / \mathrm{ml}, 0.6 \mathrm{mg} / \mathrm{ml}, 0.4 \mathrm{mg} / \mathrm{ml}, 0.2 \mathrm{mg} / \mathrm{ml}$ and $0.1 \mathrm{mg} /$ $\mathrm{ml})$.

iv. Blank was prepared by using ethanol instead of extract solution.

v. The same steps were prepared for the Gallic acid (standard) and the calibration line was plotted.

vi. The total phenolic content was calculated in term of Gallic acid equivalent (mg of GAE/g of extrtact) by using formula of: 
$\mathrm{C}=(\mathrm{A} / \mathrm{B}) \mathrm{x}$ dilution factor

C, Total phenolic content; A, $\mathrm{x}$ value; $\mathrm{x}$, regression line; $\mathrm{B}$, concentration of extract

\section{DPPH free radical scavenging assay ${ }^{16}$}

i. Different concentration of extract solution $(0.03125,0.0625$, $0.125,0.25,0.5$ and $1.0 \mathrm{mg} / \mathrm{ml})$ were prepared as well as control (methanol without extract sample).

ii. Different concentration of extract solution was subjected to the uniformly mixing.

iii. $5.0 \mathrm{ml}$ of methanolic solution of DPPH reagent was added individually to each of the different concentration of the extract solution.

iv. The mixture samples were then subjected to vortex for few minutes.

v. The mixture samples were incubated at room temperature in the dark for around 30 minutes.

vi. The absorbance for each concentration mixture samples was measured at $517 \mathrm{~nm}$ against a blank by using UV-Visible spectrophotometer.

vii. The percentage of DPPH scavenging activity was calculated using the following equation:

$\%$ Scavenging of test sample $=\frac{\text { control absorbance }- \text { test absorbance }}{\text { control absorbance }} \times 100$

viii. All the procedure was repeated for BHT solution (standard) of different concentration (similar to the previous concentration).

ix. The $50 \%$ inhibitory concentration value $\left(\mathrm{IC}_{50}\right)$ for both extracts were calculated and it is indicated as the effective concentration of the sample that is required to scavenge $50 \%$ of the DPPH free radicals.

x. The data for both extract sample and standard were obtained and tabulated.

\section{Results of antioxidant activity}

The results are shown in Table 4, Table 5, Table 6.

\section{OSESE}

\section{Table 4}

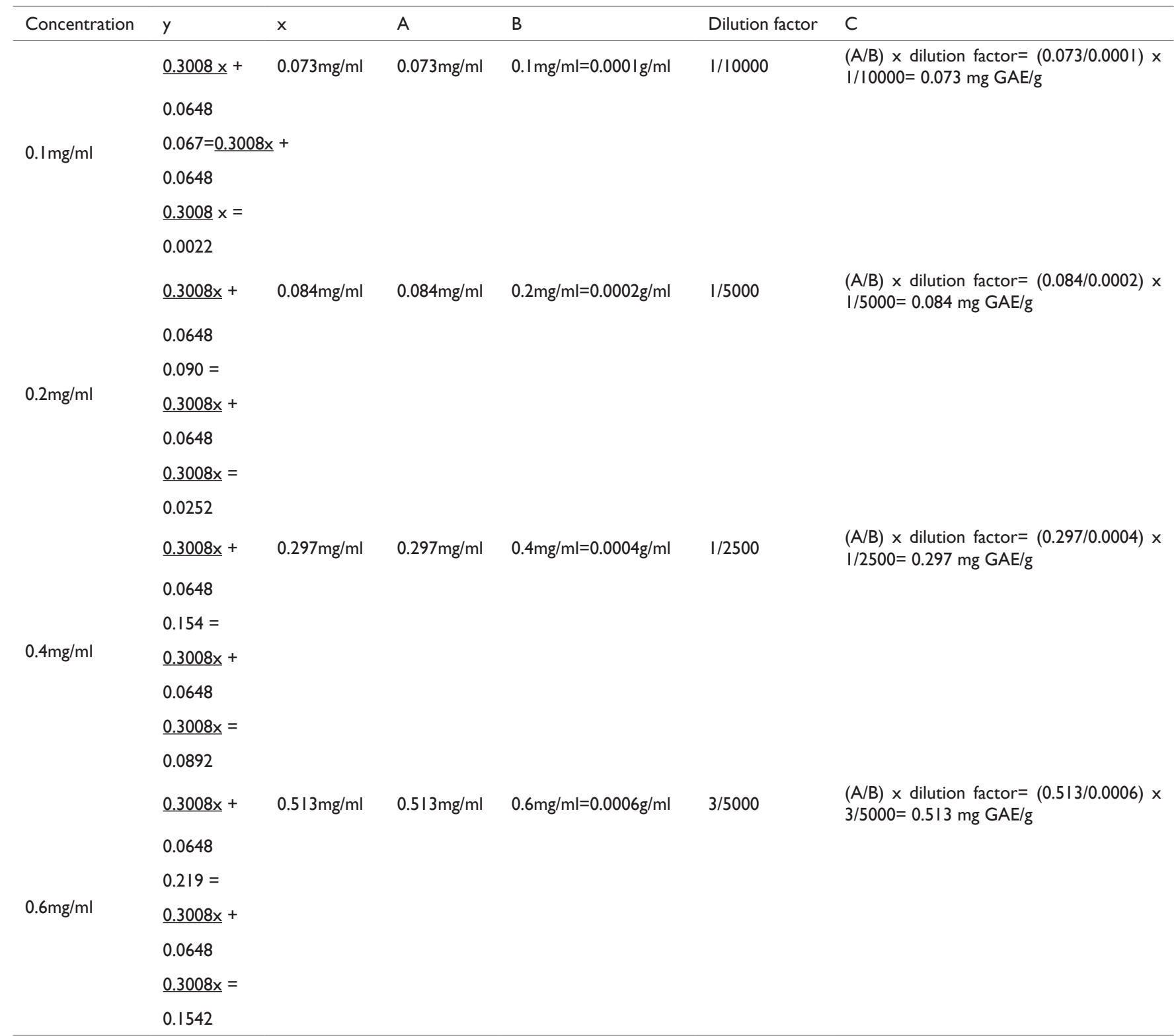


Table Continued....

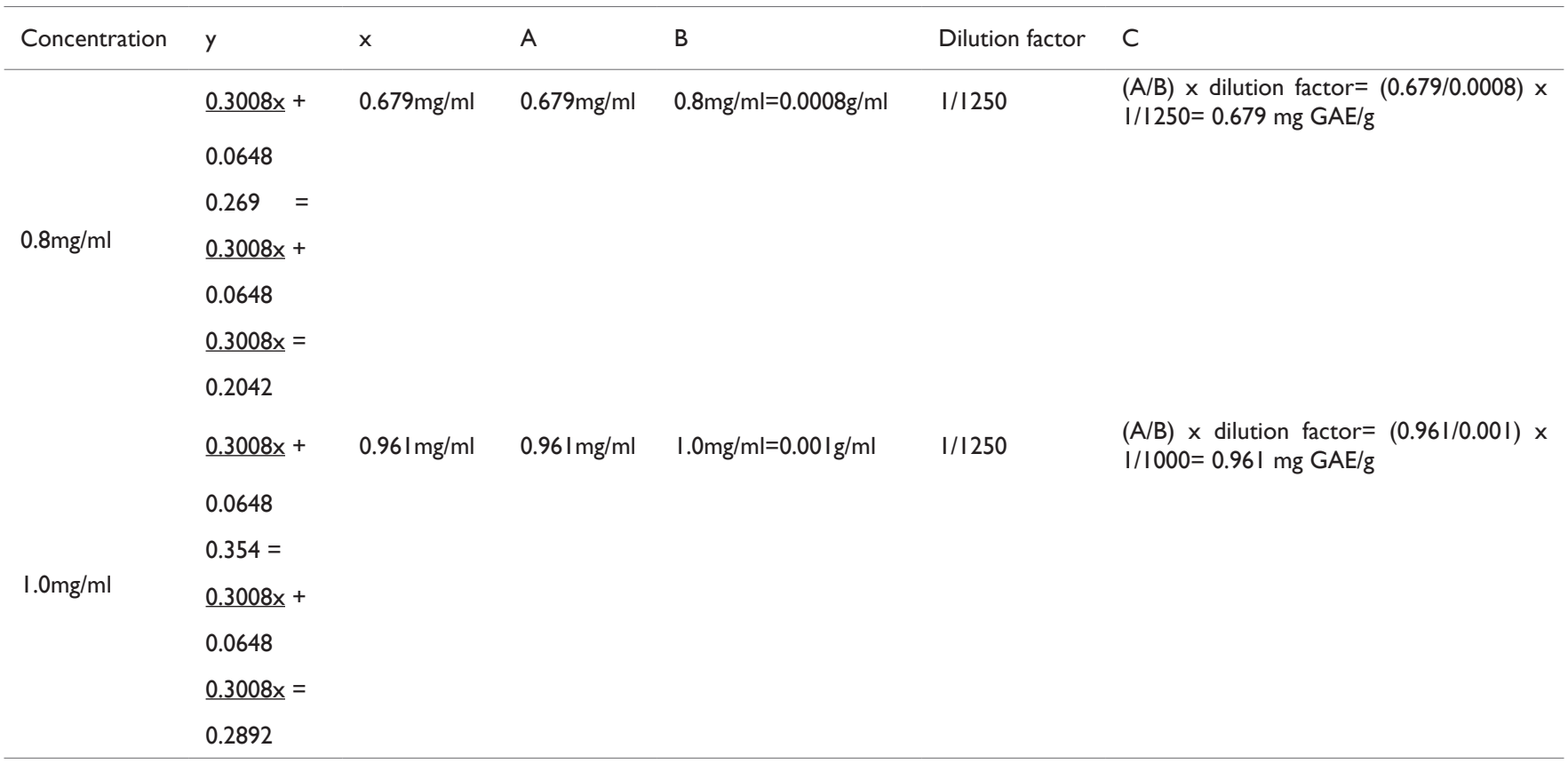

Table 5 UV absorbance of Gallic acid in various concentration

\begin{tabular}{lll}
\hline S. No & Concentration of Gallic acid $/ \mathbf{m g} / \mathbf{m l}$ & Absorbance \\
\hline I & 0.1 & 0.105 \\
2 & 0.2 & 0.126 \\
3 & 0.4 & 0.169 \\
4 & 0.6 & 0.25 \\
5 & 0.8 & 0.294 \\
6 & 1 & 0.377 \\
\hline
\end{tabular}

Table 6 Dilution factors for Gallic acid in total phenolic analysis

\begin{tabular}{|c|c|c|c|c|c|c|c|c|c|}
\hline Conc. Of Sample (mg/mL) & 100 & 10 & $\mathrm{I}$ & 0.1 & 0.2 & 0.3 & 0.4 & 0.6 & 0.8 \\
\hline Stock solution (ml) & 1000 & 100 & 10 & $\mathrm{I}$ & I & 1 & $\mathrm{I}$ & $\mathrm{I}$ & 1 \\
\hline Vol. of stock solution (ml) & 1 & 1 & 1 & $\mathrm{I}$ & 2 & 3 & 4 & 6 & 8 \\
\hline Vol. of $95 \%$ methanol (ml) & 9 & 9 & 9 & 9 & 8 & 7 & 6 & 4 & 2 \\
\hline Total Volume (ml) & 10 & 10 & 10 & 10 & 10 & 10 & 10 & 10 & 10 \\
\hline Dilution factor & $1 / 10 n$ & $1 / 100$ & $1 / 1000$ & $1 / 10000$ & $\mathrm{I} / 5000$ & $3 / 10000$ & $\mathrm{I} / 2500$ & $3 / 5000$ & $\mathrm{I} / \mathrm{I} 250$ \\
\hline
\end{tabular}

\section{DPPH free radical scavenging analysis ${ }^{18}$}

Table 7, Table 8

Table 7 Absorbance value of standard (BHT) and extract of Ocimum sanctum at $517 \mathrm{~nm}$, Control (DPPH) absorbance $=0.550$

\begin{tabular}{lll}
\hline \multirow{2}{*}{ Concentration $(\mathrm{mg} / \mathrm{ml})$} & \multicolumn{2}{c}{ UV Absorbance } \\
\cline { 2 - 3 } & BHT & OSESE \\
\hline 0.03125 & 0.442 & 0.468 \\
0.0625 & 0.32 & 0.421 \\
0.125 & 0.233 & 0.314 \\
0.25 & 0.102 & 0.168 \\
0.5 & 0.03 & 0.053 \\
$\mathrm{I}$ & 0.02 & 0.038 \\
\hline
\end{tabular}

Table 8 Percentage scavenging of BHT and OSESE in DPPH assay

\begin{tabular}{lll}
\hline \multicolumn{2}{l}{ DPPH ASSAY } & \multicolumn{2}{l}{ \%Scavenging } \\
\cline { 2 - 3 } Concentration $(\mathrm{mg} / \mathrm{ml})$ & BHT & OSESE \\
\hline 0.03125 & 19.64 & 14.91 \\
0.0625 & 41.82 & 23.45 \\
0.125 & 57.64 & 42.91 \\
0.25 & 81.45 & 69.45 \\
0.5 & 94.55 & 90.36 \\
\hline & 96.36 & 93.09
\end{tabular}




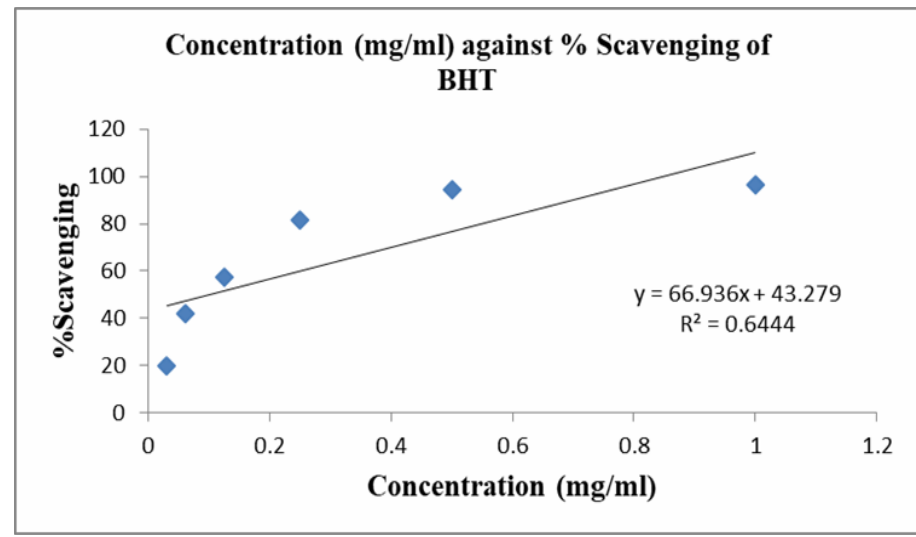

$\mathrm{IC}_{50}$ $0.1 \quad 0.25$

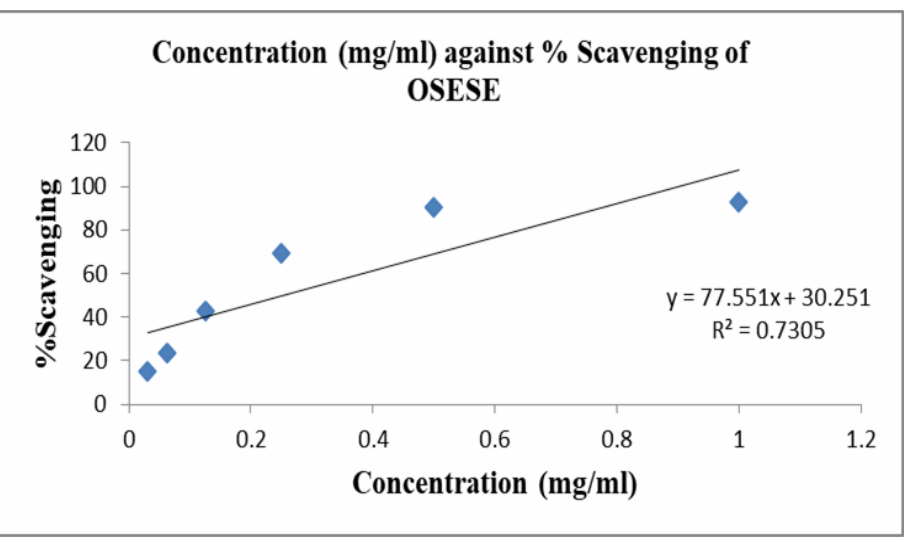

Graph 2 Concentration against \% scavenging of butyl hydroxyl toluene

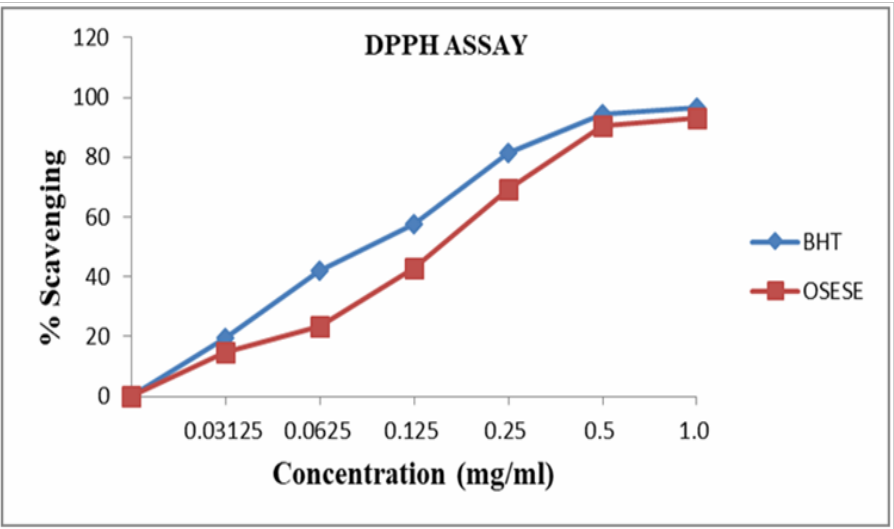

(BHT).

Graph 3 Concentration against \% scavenging of OSESE.

Graph 4 Percentage scavenging against concentration for both BHT and OSESE.

Graph 4 shows a gradually decrease in the scavenging ability of the OSESE sample to the standard BHT. OSESE shows $\mathrm{IC}_{50}$ of $0.25 \mathrm{mg} / \mathrm{ml}$ which was comparable to BHT with $\mathrm{IC}_{50}$ of $0.10 \mathrm{mg} / \mathrm{ml}$. The $\mathrm{IC}_{50}$ of BHT was calculated by the equation which plotted from the standard graph of BHT as shown in Graph 2 and the $\mathrm{IC}_{50}$ of OSESE was calculated by the equation plottedfrom the graph of concentration against \% scavenging of OSESE as shown in Graph 3.

\section{For BHT:}

\begin{tabular}{|c|c|}
\hline & $\mathrm{IC}_{50}$ \\
\hline & $Y=M X+C$ \\
\hline & $50=66.936 x+43.279$ \\
\hline & $66.936 x=50-43.279$ \\
\hline & $66.936 x=6.721$ \\
\hline & $6.721 / 66.936$ \\
\hline & $0.1 \mathrm{mg} / \mathrm{ml}$ \\
\hline \multicolumn{2}{|l|}{ For OSESE: } \\
\hline \multicolumn{2}{|c|}{$\mathrm{IC}_{50}$} \\
\hline \multicolumn{2}{|c|}{$Y=M X+C$} \\
\hline \multicolumn{2}{|r|}{$50=77.551 x+30.251$} \\
\hline \multicolumn{2}{|r|}{$77.551 x=50-30.25 I$} \\
\hline \multicolumn{2}{|r|}{$77.551 x=19.749$} \\
\hline$x=$ & |9.749/77.55| \\
\hline$x=$ & $0.25 \mathrm{mg} / \mathrm{ml}$ \\
\hline
\end{tabular}

In DPPH scavenging method, the result obtained for OSESE at $1.0 \mathrm{mg} / \mathrm{ml}$ stock concentration was $93.09 \mathrm{mg} / \mathrm{ml}$ whereas in total phenolic content analysis, the result obtained for OSESE at $1.0 \mathrm{mg} / \mathrm{ml}$ stock concentration was $0.961 \mathrm{mg} \mathrm{GAE} / \mathrm{g}$.

\section{Conclusion}

Hence, this can be proved that this extract has the antioxidant potential. The preliminary in- vitro antibacterial screening of Ocimum sanctum was not effectively showed any control over the growth of the test bacteria strains due to low concentration used in this study. To have more insight into the antibacterial screening, further investigation on isolates of extracts should be done perfectly. Ocimum sanctum has shown substantial antioxidant activity through total phenolic content analysis and DPPH radical scavenging analysis. It is concluded that there is a good antioxidant potential of Ocimum sanctum with ethanolic Soxhlet extraction.

\section{Funding details}

The authors are grateful to the Faculty of Pharmacy, AIMST University, Bedong, Kedah D.A., Malaysia for funding and providing entire research facilities.

\section{Acknowledgments}

None.

\section{Conflicts of interest}

Authors declare that there is no conflict of interest.

\section{References}

1. Ocimum tenuiflorum (holy basil). Wallingford: CABI; 2018. 
2. Holy Basil-Ocimum tenuiflorum-Extant \& Habitat resource-Overview. Encyclopedia of Life; 2018.

3. Tulsi, Holy Basil (Ocimum Sanctum)-Medicinal Properties, Benefits \& Dosage. Planetayurveda; 2018

4. Prakash P, Gupta N. Therapeutic uses of Ocimum sanctum Linn (Tulsi) with a note on eugenol and its pharmacological actions: a short review. Indian J Physiol Pharmacol. 2005;49(2):125-131.

5. Pattanayak P, Behera P, Das D, et al. Ocimum sanctum Linn. A reservoir plant for therapeutic applications: An overview. Pharmacogn Rev. 2010;4(7):95-105.

6. Sethi J, Sood S, Seth S, et al. Evaluation of hypoglycemic and antioxidant effect of Ocimum sanctum. Indian J Clin Biochem. 2004;19(2):152-155.

7. Singh AR, Bajaj VK, Sekhawat PS, et al. Phytochemical estimation and Antimicrobial activity of Aqueous and Methanolic extract of Ocimum Sanctum L. J Nat Prod Plant Resour. 2013;3(1):51-58.

8. Joseph B. Ethanopharmacological and Phytochemical Aspects of Ocimum sanctum Linn-The Elixir of Life. British Journal of Pharmaceutical Research. 2013;3(2):273-292.

9. Almashhedy LAM. Estimation of the phytochemical constituents and biological activity of Iraqi Ocimum sanctum L. extracts. International Journal of Pharma and Bio Sciences. 2014;6(1):999-1000.

10. Rajesh H. Phytochemical analysis of aqueous extract of Ocimum sanctum linn. Int J Pharm Bio Sci. 2013;2:462-468.

11. Rahman S, Islam R, Kamruzzaman M, et al. Ocimum sanctum L.: A Review of Phytochemical and Pharmacological Profile. Am $J$ Drug Discov Dev; 2011. 15 p.

12. Verma S. Chemical constituents and pharmacological action of Ocimum sanctum (Indian holy basil-Tulsi). J Phytopharmacol. 2016;5(5):205207.

13. Mistry KS, Sanghvi Z, Parmar G, et al. The antimicrobial activity of Azadirachta indica, Mimusops elengi, Tinospora cardifolia, Ocimum sanctum and $2 \%$ chlorhexidine gluconate on common endodontic pathogens: An in vitro study. Eur J Dent. 2014;8(2):172-177.
14. Pawar BT, Pandit BD. Antibacterial activity of leaf extracts of Ocimum sanctum L. against Xanthomonas campestris pv. mangiferaeindicae. Res J Recent Sci. 2014;3:291-294.

15. Jorgensen JH, Ferraro MJ. Antimicrobial Susceptibility Testing: A Review of General Principles and Contemporary Practices. Clin Infect Dis. 2009;49(11):1749-1755.

16. Khan NH, Ying ALT, Tian CGZ, et al. Screening of Punica Granatum seeds for antibacterial and antioxidant activity with various extracts. Journal of Biotechnology and Phytochemistry. 2017;1(1):1-7.

17. Reglinski M, Sriskandan S. Streptococcus pyogenes. Molecular Medical Microbiology; 2015. 675-716 p.

18. Sreelatha S, Padma P. Antioxidant Activity and Total Phenolic Content of Moringa oleifera Leaves in Two Stages of Maturity. Plant Foods Human Nutr. 2009;64(4):303-311.

19. Vijayalakshmi S, Arunkumar V, Anju D, et al. Comparative antimicrobial activities of Emblica officinalis and Ocimum sanctum. Anc Sci Life. 2007;27(2):1-6.

20. Sailaja I, Anand Shaker I. Antioxidant activity in Ocimum sanctum Linn, Ocimum bascilicum. Asian Journal of Bio Science. 2010;5(2):195-199.

21. Bandita Deo, Monalisha Nath, Preetam Kumar Nayak, et al. Evaluation of antioxidant activity of ocimum tenuiflorum, an important medicinal herb. International Journal of Plant, Animal and Environmental Sciences. 2013;3(2):150-154.

22. Mohan L, Amberkar MV, Kumari M. Ocimum sanctum linn (tulsi)-an overview. Int J Pharm Sci Rev Res. 2011;7:51-53.

23. Pisoschi AM, Negulescu GP. Methods for Total Antioxidant Activity Determination: A Review. Biochem \& Anal Biochem. 2011;1:106.

24. Warsi, Sholichah A. Phytochemical screening and antioxidant activity of ethanolic extract and ethyl acetate fraction from basil leaf (Ocimum basilicum L.) by DPPH radical scavenging method. IOP Conference Series: Materials Science and Engineering. 2017;259:012008.

25. Batta SK, Santhakumari G. The antifertility effect of Ocimum sanctum and Hibiscus Rosa Sinensis. Indian J Med Res. 1971;59(5):777-781. 